\title{
Foucault Studies
}

(C) Alex Feldman

ISSN: 1852-5203

DOI: https://doi.org/10.22439/fs.v25i2.5584

Foucault Studies, No. 25, 274-298, October 2018

ARTICLE

\section{The Genesis of Foucault's Genealogy of Racism: Accumulating Men and Managing Illegalisms}

\author{
ALEX FELDMAN
}

\begin{abstract}
Foucault's contribution to the critical theorization of race and racism has been much debated. Most commentators, however, have focused on his most direct remarks on the topic, which are found in the first volume of the History of Sexuality and in the lecture course "Society Must Be Defended." This paper argues that those remarks should be reread in light of certain moves Foucault makes in earlier lecture courses, especially The Punitive Society and Psychiatric Power. Although the earlier courses do not always explicitly address the theme of race, the concepts of the "accumulation of men" and the differential "management of illegalisms" developed in them immensely enrich Foucault's outline of a genealogy of racism. They also permit a clarification of the problem to which the concept of "state racism" is an answer, and they provide the key for understanding the wider social conditions of state racism. The guiding thread linking these earlier courses to the later material is the problem of a genealogy of logics of enmity. At the same time, the earlier courses make explicit the link between these logics and the development of capitalist society.
\end{abstract}

Keywords: Foucault; racism; race; Marx; illegalism; capital.

\section{INTRODUCTION}

Foucault never wrote his book Populations and Races. ${ }^{1}$ Indeed, he said little overall about race and racism, despite the suggestive indications in his 1976 introduction to the History of Sexuality and in "Society Must Be Defended," his lecture course from the same year (hereafter, WK and SMBD respectively). Nearly every one, however, of Foucault's investigations from his first cycle of courses at the Collège de France dances around the problematic of race: race is signaled, often in passing, but rarely thematized. The shortcomings of Foucault's statements on the subject, including above all his tendency to elide the

\footnotetext{
${ }^{1}$ The back cover to the first edition of the first volume of the History of Sexuality listed five future titles. Populations et races was to be the final volume in the series. See Arnold I. Davidson, "Ethics as Ascetics: Foucault, the History of Ethics, and Ancient Thought," in The Cambridge Companion to Foucault, ed. Gary Gutting, 2nd ed. (2005), 125.
} 
context of slavery, colonialism, and imperialism and to approach modern European racialism from a strictly intra-European archive, have been much discussed. ${ }^{2}$ At the same time, it is undeniable that many critical theorists of race and colonialism have found Foucault's methods and concepts fruitful when applied to periods and areas about which he himself did not write. ${ }^{3}$

Whatever their tone, these engagements with Foucault on race and racism have focused mainly on the short pronouncements from 1976. I would like to suggest a different approach in this paper, one that would, ideally, look at the place of race across all of his writings, but that, for the sake of space, will focus here on the period 1971-1976, from his election to the Collège de France to his sabbatical year (1977). There is a certain convergence between Foucault's political activity with the Prisons Information Group (GIP), the lecture courses, and the two books he published during his most intensely political phase. Politically, the memory not only of fascism, but also of Algerian decolonization, and, more particularly, of the anti-Algerian pogrom in Paris on 17 October 1961, appears to have been the implicit background of much of his thought. ${ }^{4}$ The lecture courses from 1971-1976, for their part, are always concerned to illuminate both the present struggles and the changes underway in capitalist society and bourgeois hegemony. It is against this double backdrop that Foucault's 1976 discussions of racism should be situated.

What Foucault has to offer, then, to the project of a genealogy of racism goes well beyond what he explicitly stated in WK and SMBD. Now, WK and SMBD, insofar as they treat racism at all, focus particularly on state racism (racisme d'État). This concept is certainly of interest, especially as a counterweight to conventional liberal discourse on racism, which treats it primarily as a matter of individual prejudice or belief and not as a style of state practice. Yet I hope to show in what follows how the remarks on state racism from WK and SMBD are rooted in a larger problematic, one that develops slowly and only in outline in the earlier lecture courses. Foucault has not one but several accounts of racism, or rather the account of state racism from 1976 itself relies on this larger problematic. My goal is to bring to light a more internally differentiated and articulated approach to racism than is typically read in Foucault, thereby making him more

\footnotetext{
2 There has been a growing literature on this topic since the mid-1990s. Some highlights include Robert Young, "Foucault on Race and Colonialism," New Formation 25 (1995), 57-65; Ann Laura Stoler, Race and the Education of Desire: Foucault's History of Sexuality and the Colonial Order of Things (1995); Robert Bernasconi, "The Policing of Race Mixing: The Place of Biopower within the History of Racisms," Journal of Bioethical Inquiry 7.2 (2010), 205-16. Edward Said had a particularly ambivalent relationship with Foucault's thought. After an initial embrace of Foucault's archaeological methods (e.g., in Edward W Said, Beginnings: Intention and Method (1975), 282-315), Said eventually came to find in Foucault an overwhelming Eurocentrism (Edward W. Said, Reflections on Exile and Other Essays, (2000), 195-196.

${ }^{3}$ See the preceding note, especially Stoler, Race and the Education of Desire. Consider also the work of Santiago Castro-Gomez, e.g., Santiago Castro-Gómez, "Michel foucault y la colonialidad del poder," Tabula Rasa 6 (2007), 153-72.

${ }^{4}$ Foucault and Vidal-Naquet mention the significance of this event in an interview from 1971. Michel Foucault and Pierre Vidal-Naquet, "Enquête sur les prisons: brisons les barreaux du silence," in Dits et écrits. 1954-1975, ed. Daniel Defert, François Ewald, and Jacques Lagrange, vol. 1 (2001), 1050. All references to the Dits et écrits are hereafter abbreviated DE, followed by the volume and text number. See also Alain Brossat, “Le peuple, la plèbe et la pègre," Lignes 21.1 (1994), 35.
} 
available for contemporary critical philosophy of race. The first part of the paper will explore the concept of state racism in SMBD and bring to light its presuppositions. In the second part of the paper, I will examine these presuppositions. The emergence of state racism in Foucault's account is dependent upon the functioning of a new technology of power, biopower, but the concrete deployment of this technology must be understood in ways that only become clear once we look back from SMBD to such earlier lecture courses such as The Punitive Society (1973) and Psychiatric Power (1973-4), as well as to Discipline and Punish. The lecture courses, in particular, develop two concepts that any serious treatment of Foucault on racism should henceforth take up: the "accumulation of men" and the "management of illegalisms."

\section{THE CONCEPT OF STATE RACISM}

The famous lecture of 17 March 1976 from SMBD is less a free-standing document than a very condensed summary of five or six years of reflection. This lecture, indeed, gives nothing more than a brief indication of a work in progress (Populations and Races) that was never completed. ${ }^{5}$ Now that the Collège de France courses have all been published, it is much easier to treat SMBD in its context. It is the end of Foucault's first cycle of courses at the Collège de France, an end that marks the closure of the research program Foucault had laid out in his inaugural lecture. ${ }^{6}$

Foucault is quite explicit that the objective of SMBD is not a genealogy of racism, but rather (a) a genealogy of war as "grid of intelligibility" for history and (b) a genealogy of discourses of and on the state. ${ }^{7}$ SMBD thus stands as a bridge between the early courses at the Collège de France, which carry out a genealogy of the modern repressive state apparatus ("armed justice") from a quasi-Marxist approach, and the courses from 19781979, which investigate the emergence of a specific rationality of statecraft or raison $d^{\prime}$ Etat. ${ }^{8}$ Historical understanding and state reason are the central themes of SMBD, not racism. Insofar as Foucault is concerned with the problematic of racism, it is with the

\footnotetext{
${ }^{5}$ See Box 12 of the Fonds Foucault (NAF 28730) at the Bibliothèque Nationale (Paris, consulted 19-20 May 2017). The reading notes I found there go well beyond what Foucault covers in SMBD. The folder marked "Races et histoires," in particular, contains detailed information on Saint-Simonian theories of race-mixing, including work by Gustave d'Eichthal and Victor Courtet, two figures who Bernasconi argues are crucially missing from Foucault's account of the transition from an historiographical to a biomedical race discourse. Bernasconi, "The Policing of Race Mixing," 209-210.

${ }^{6}$ On the organization of the first cycle of lecture courses, see Michel Senellart, "Le cachalot et l'écrevisse. Réflexions sur la rédaction des cours au Collège de France," Cahiers de l'Herne 95 (2011), 147-55.

${ }^{7}$ Michel Foucault, "Il faut défendre la société": cours au Collège de France, 1975-1976, Hautes études (1997), 7577; Michel Foucault, "Society Must Be Defended": Lectures at the Collège de France, 1975-76, ed. Mauro Bertani, Alessandro Fontana, and François Ewald (2003), 87-89.

${ }^{8}$ Foucault's second course at the Collège de France, in particular, is concerned with the birth of the absolutist state. Michel Foucault, Théories et institutions pénales: cours au Collège de France, 1971-1972, ed. François Ewald, Alessandro Fontana, and Bernard E. Harcourt, Hautes études (2015). On the genealogy of raison d'Etat, see Michel Foucault, Security, territory, population: lectures at the Collège de France, 1977-1978, ed. Michel Senellart (2009), lectures of 8 March 1978 and following.
} 
emergence specifically of state racism (racisme d'Etat). The "birth" of state racism is the avowed theme of the lecture of 17 March $1976 .{ }^{9}$

A word is needed here on the term "state racism" itself. At first glance, racisme d'Etat would appear to refer to racist action carried out by the state or racist ideology adopted by state actors, and Robert Hurley sometimes goes so far as to translate it as "statedirected racism." 10 The state in such a translation is taken as a subject with the property or predicate of being racist. But the question really is why the state appears to be a selfstanding thing with racist properties and why racism, in turn, plays a role in establishing this appearance. For the state to direct racism, there must have been a certain prior racialization that the state can put at its disposal. There must also be something like a state in the first place. If racism is to be grasped, not as ideology or prejudice, but as a form of power-knowledge, then the ways in which race is at issue in state racism should be carefully specified. For these reasons, it would perhaps be more helpful to speak of state racialism, or of the "racial state." David Theo Goldberg lists five functions performed by the racial state:

1. Define populations into racial groups.

2. Regulate relations of different types between these groups so defined.

3. Govern populations in terms of their race.

4. Manage the economy and economic life and labor of racially-defined groups.

5. Mediate relations as neutral "adjudicator" in addition to regulating them. ${ }^{11}$

The larger question to which the concept of state racism is an answer is twofold. First, how does the state assume control over a particular (racial) way of classifying, organizing, and managing people? Second, how does this control permit, in turn, the state to appear as a unified and self-standing authority? Put simply, the question of state racism for Foucault is a question both of what the state does and how something like the state appears on the scene.

The general tendency in much liberal talk on racism has been to conceive racism as differential treatment according to a "morally irrelevant category." 12 If the state itself does sometimes engage in just this sort of differential treatment on the basis of race, the more fundamental question, from the vantage of a critical account of state racialism/the racial state, concerns the way in which the state is involved in determining the practical meaning of race itself and in assuring that something like race will appear in particular locations in the first place-and appear with a certain "obviousness" (évidence) and acceptability to those concerned. How does this category arise, take hold, and become so relevant for so many lives?

\footnotetext{
${ }^{9}$ Foucault, Il faut défendre la société, 213; Foucault, Society Must Be Defended, 239. See also Race and the Education of Desire, 56.

${ }^{10}$ E.g., Michel Foucault, La volonté de savoir (1976), 157; Michel Foucault, The History of Sexuality, Vol. 1: An Introduction (1990), 119.

${ }^{11}$ David Theo Goldberg, The Racial State (Blackwell, 2002), 110-111.

12 See the discussion of the work of Joel Feinberg and John Rawls in David Theo Goldberg, Racist Culture:

Philosophy and the Politics of Meaning (1993), $6 \mathrm{ff}$.
} 
In SMBD, Foucault broaches something like Goldberg's first two functions. He asks how an earlier discourse of the war of races (the plural is, of course, very important for Foucault) is reinterpreted into state racism. Foucault sees this earlier discourse as having been not only outside the state, but also revolutionary at many moments. ${ }^{13} \mathrm{He}$ associates it in particular with the radical movements of the English Civil War. Race is not a stable biological distinction in these discourses, but rather a "historico-political" distinction. ${ }^{14}$ It functions as an element in a logic of enmity, one that makes social division intelligible as a binary relation between conquerors and conquered, rather than as the standard tripartite ordering of feudal society; social hierarchies are read as manifestations of unconcluded struggle, and not of peace and order. ${ }^{15}$ At the end of the eighteenth century, the state takes over this discourse and in so doing transforms it. Race discourse remains, fundamentally, a logic of enmity, even as it is biologized and "statified". When this logic passes into the state, the binary system is replaced by a "biologically monist" logic of the social. The enemy is not an external conqueror who threatens the state from a position of a comparable footing to the state; the enemy is now the disqualified ennemi intérieur, an "accidental" pathogen affecting the population body. ${ }^{16}$

Foucault's historical details are questionable for the reasons raised above. Nevertheless, this approach makes a major contribution in emphasizing the link between race discourse and the discourse of enemyship; my position below will be that we should look elsewhere in Foucault for the prehistory of state racism as logic of enmity. A central component of state reason is the working out of a logic or technology of enmity. A genealogy of the logic of enmity of the modern state would then stand alongside the other genealogies of power technologies that Foucault carries out more explicitly in the 1970s. But a genealogy of technologies of enmity assumes a particular importance for Foucault in light of the larger framing he gives to his own project in the 1970s: he proposes to grasp the social as a site of conflicting strategies. Indeed, at the limit, he proposes several times to use the concept of civil war as an "analyzer of social relations." Rather than seeing the state as the resolution of civil war (Hobbes' position), Foucault treats it as one more strategy in a multi-party civil war for which the very terms and terrain on which the struggle is to be waged constitute a central site of struggle. ${ }^{17}$ The question we will have to take up in the next section, then, is how the genealogy of state racism should be situated with respect to Foucault's other genealogies of logics of enmity.

In short, the racism of state racism should not be understood exclusively as the state's practice of treating various racial groups differentially or as an ideology promoted by the state. Differential treatment and ideology must be grasped as consequences of a more fundamental framework: a certain rationality of struggle and enemyship that relies on a historically-dynamic category of race. This rationality aims first of all at establishing

\footnotetext{
${ }^{13}$ Il faut défendre la société, 68-69; Society Must Be Defended, 78-79.

${ }^{14}$ Il faut défendre la société, 67-69; Society Must Be Defended, 77-79.

${ }^{15}$ Il faut défendre la société, 64-65; Society Must Be Defended, 74.

${ }^{16}$ Il faut défendre la société, 70; Society Must Be Defended, 80-81.

${ }_{17}$ Michel Foucault, La société punitive: cours au Collège de France, 1972-1973, ed. François Ewald (2013), 14-15, $26-34$.
} 
that and what races are (what I have called "racialism") by taking up a prior practicoracial articulation of the world. It takes over the management of the political significance of race and controls the assignment of bodies to races ("racialization"), all of which corresponds, roughly, to Goldberg's third function. What remains to be clarified is the relationship between this strategic logic of enmity and the state. In SMBD, Foucault proposes the following: the "new technology of power" (biopower) serves to "inscribe" racism in the "fundamental mechanism" of the state. ${ }^{18}$ The lecture of 17 March 1976, however, focuses primarily on the first part of this statement, namely, on the character of biopower. The unresolved problem, here, is twofold: how (and in what sense) was racism inscribed in the fundamental mechanism of the state, and "where" was racism (what was it like and how did it function) before this moment of inscription (such that it could lend itself to being inscribed in the state)?

Foucault was once widely taken to have denied the importance of the state as a site of political struggle and an object of analysis. Later, it was recognized that the courses from 1978-1979 offer an original and non-essentialist contribution, through the lens of governmentality, to thinking about the state. The new picture of Foucault on the state, however, is also misleading: it portrays him as having started with the microphysical and the local and then progressively moved toward an account of more global strategies. ${ }^{19}$ But even at his most "microphysical" moment, Discipline and Punish, Foucault still feels compelled to address the problem of the state. He wants to show how the police, as a new state apparatus, emerges through a process of étatisation of a wider network of power relations (the disciplines), relations that retain a certain autonomy with respect to state apparatuses while allowing for the wider range and effectivity of these apparatuses. ${ }^{20}$ (Étatisation normally translates as "nationalization," in the sense of nationalizing the mines, but here I will use "statification" to preserve the clear reference to the state; the term is omnipresent in Foucault's work from 1971-5, but is rarely translated consistently.) With the lecture courses in view, it is now clear that Foucault starts with the problem of the repressive apparatus of the state, then works back from it to a new, microphysical approach to power, before returning to the state in the lecture courses on governmentality (1978-9). ${ }^{21}$ Two stages might be distinguished. In the first phase, from 1971-1976, Foucault engages in an extended critique of the Marxist theory of state apparatuses, but this

\footnotetext{
18 Il faut défendre la société, 227; Society Must Be Defended, 254.

${ }^{19}$ Representative of this view and of the overall shift in interpretation is Bob Jessop, "From Micro-Powers to Governmentality: Foucault's Work on Statehood, State Formation, Statecraft and State Power," Political Geography 26.1 (2007), 38-39.

${ }^{20}$ Michel Foucault, Surveiller et punir: naissance de la prison [1975](1993), 248ff; Michel Foucault, Discipline and Punish: The Birth of the Prison (1995), 213ff. Foucault will, of course, largely abandon this concept after 1978. Michel Foucault, Sécurité, territoire, population: cours au Collège de France, 1977-1978, ed. Michel Senellart and François Ewald (2004), 112; Foucault, Security, territory, population, 109.

${ }^{21}$ The 1972 course has as its explicit object of study the birth of the state repressive apparatus. Foucault, Théories et institutions pénales, 41, 172.
} 
critique shares many of that theory's central terms and questions. ${ }^{22}$ The problem of the state is essentially the problem of the statification of certain social tactics in the service of maintaining social order and ensuring capital accumulation. The second phase, from 1978 on, shifts to the question of the relationship between governmentality and the state. ${ }^{23}$

SMBD belongs to the end of the first stage, which is our present focus. We can thus look backwards to get a sense of what Foucault means by the "inscription" of racism in the "mechanism" of the state. Although Foucault is, from the very beginning of this first period, critical of the metaphor of a state apparatus (appareil), he nonetheless approaches the state as a mechanism or a machine. Balibar, in his history of the metaphor of the apparatus in Marxist theory, notes that it tends to revolve around two distinct problems whose link is not always made clear: the problem of ideology and the problem of repression. On the one hand, to treat the state as a bundle of machines (and not an organism) is to deny it any essence, or the unity of an idea. On the other hand, the mechanical approach grasps the form of connection between the members of the community as one of repression and coercion, rather than shared ethical life. ${ }^{24}$ In the first case, to speak of a state apparatus is to challenge the state's pretention to incarnate a unified source or essence. It is to demystify the representative organs of the state, which claim to be the authorized agents of the community as a whole. In the second case, to speak of a state apparatus is to explain away this semblance of unity as nothing other than a non-organic, coercive connection between conflicting parts.

Foucault, to be sure, does not take over the tradition of apparatus theory wholesale. In particular, he thinks that the notion of a state apparatus tends to lead to a conception of power as emanating from a central point (the state), whereas the state is merely the "concentrated form" of a larger "system of power." 25 One might say that Foucault shares with the traditional Marxist theory of state apparatuses an overall materialist orientation toward the state, if materialism is understood to mean primarily an anti-idealism rather than a doctrine of matter. Nevertheless, he marks two changes in the problematic. For the question of repression, he substitutes an analysis of power relations in their multiplicity and heterogeneity, as well as in their forms of synthesis and combination; for the questions of representation, ideology, and legitimacy, he substitutes the question of the "acceptability" or "self-evidence" (évidence) of a system of power.

In sum, when Foucault speaks of the inscription of racism in the mechanisms of the state, he means that racism becomes a tool or device not only of repression, but also, as we have already said, of power relations more generally. Second, racism plays a role in

\footnotetext{
${ }^{22}$ See Théories et institutions pénales, 167-176, as well Foucault, Société punitive, 233-4; translated as Michel Foucault, The Punitive Society: Lectures at the College de France 1972-1973, ed. Bernard E. Harcourt and Alessandro Fontana (2015), 229-230.

${ }^{23}$ The new approach focuses especially on the "reflective practice" or savoir of the state (Security, territory, population, 247, 277). But echoes of this approach can be found as early as Société punitive, 238.

${ }^{24}$ Etienne Balibar, "Appareil," in Dictionnaire critique du marxisme, ed. Gérard Bensussan and Georges Labica (1999), 47-48.

${ }^{25}$ Société punitive, 233-4; Punitive Society, 229-230.
} 
securing the acceptability of a system of power. It legitimates the state, which takes on the position of guarantor of social defense against the dangerous elements. It also renders acceptable a wider system of strategies and the power technologies underwriting social defense.

\section{RACE AND ENMITY}

"An entire social practice, of which state racism was both the intensified [exaspéré] and the coherent form, gave this technology of sex a formidable power and far-reaching effects." 26

In the previous section, we sought to clarify the concept of state racism, especially as Foucault uses it in the final lecture of SMBD. The central genealogical problem was the inscription of a racial logic of enmity and struggle in the mechanisms of the state. What does this inscribing, Foucault says, is the emergence of a new technology of power, biopower. This concept is familiar enough today. Roughly speaking, the concept of biopower is meant to clarify how, in the nineteenth century, power gets a new type of a hold (prise) on people insofar as they are living beings. Foucault calls this process the "statification of the biological" (étatisation du biologique). ${ }^{27}$ By "statification of the biological," Foucault does not primarily mean that state reason now begins to take the results of the new biological sciences into account; he means, rather, that the political character of life and death changes. Life and death are limit points for any theory of sovereignty and its rights, prerogatives, and powers. As Rousseau so tellingly puts it, under the social contract, the citizen's "life is no longer only a kindness of nature, but a conditional gift of the state." 28 The very establishment of the state here presupposes that what seem to be natural limits or points of exteriority to the political order, birth and death, should in fact be included in the order itself.

Sovereignty, in its theory (Bodin, Hobbes, etc.) and its practice, gets a hold on life and death in this sense primarily by asserting and exercising a twofold right. According to Foucault, the theories of sovereignty all, more or less, amount to reflections on the rights of the sovereign, and chief among these is the right to make someone die (faire mourir) or let someone live. ${ }^{29}$ In the actual practice of sovereignty, however, this right plays out primarily as a right to kill legitimately - that is, in the execution of criminals and the conduct of war. The right to "let live" is not as developed. In this open place, a new "new right" (un nouveau droit) develops in the nineteenth century, albeit not quite in the same form as the old rights: a right to "make [someone] live and let [someone] die." 30

\footnotetext{
${ }^{26}$ Emphasis added. Foucault, Volonté de savoir, 157; Foucault, History of Sexuality, Vol. 1, 119. Hurley's translation has "state-directed racism" for racisme d'Etat.

${ }^{27}$ Il faut défendre la société, 212; Society Must Be Defended, 239-240.

${ }^{28}$ Rousseau, On the Social Contract, Book II, Chapter 5 (Jean-Jacques Rousseau, Basic Political Writings, ed.

Donald A. Cress, 2. ed (2011), 176-77).

${ }^{29}$ Il faut défendre la société, 214-5; Society Must Be Defended, 240-241.

30 Il faut défendre la société, 214-215; Society Must Be Defended, 241.
} 
This "right" does have, to some extent, a juridical basis, but its acceptability really arises from the formation of the new technologies of power characteristic of biopower.

Biopower is sometimes taken to be a mere a politics of fostering life. Racism appears, then, to be its murderous counterpart. In fact, the compressed account at the end of the lecture of 17 March 1976 is much more complicated than that. The privileged object of biopolitical intervention, the population - "a global mass that is affected by overall processes characteristic of birth, death, production, disease, etc." -is, crucially, a new kind of political figure. The life to be fostered is at once a biological and a civil or political life. ${ }^{31}$ The population stands in as a new way of constituting the political Same, or as a new figure of friendship. But once the political Same is constituted in this way, the door opens for a new conception of enmity, one not between rival adversaries or similar status, but now between a "biological continuum" and pathogenic threats or deviations from within that continuum. Biopower does not just foster life; it constitutes the population as a new theater of struggle between enemies, albeit one in which the struggle is now asymmetrical, to say the least.

Within this new theater, racism introduces a break in the "biological continuum of the human species," or into this population-whole. ${ }^{32}$ Mary-Beth Mader has aptly shown just how much the very appearing of such a biological continuum depends on the breakdown of the classical episteme charted in The Order of Things. ${ }^{33}$ But this shift from the discourse of natural history to that of biology is paired, here, with a corresponding shift in the discourse of enmity itself. We must bring to light the formation of a corresponding political continuum that is interwoven with this biological one. Foucault suggests that racism - or rather, racialism and racialization (see section I above) - has two chief functions in a system of biopower. First, racism introduces the "break between those who must live and those who must die." It creates a new principle of division within the biologico-political continuum. ${ }^{34}$ It also has the second function:

Putting to death [la mise à mort], the imperative of death, is only receivable in the system of biopower if it aims not at victory over political adversaries, but at the elimination of biological danger and the reinforcement, directly tied to this elimination, of the species itself or of the race. Race, racism, is the condition of acceptability of putting to death in a society of normalization. ${ }^{35}$

Racism is what makes the recoding of enmity acceptable.

Foucault sometimes describes the murderous function of racism as if it is a return of the logic of sovereignty and is extrinsic to the logic of biopower. Even if we grant him that point, it does little in the way of explaining why such a logic persists or indeed why

\footnotetext{
31 Il faut défendre la société, 216; Society Must Be Defended, 242-3.

32 Emphasis added; translation corrected. Il faut défendre la société, 227; Society Must Be Defended, 255.

${ }^{33}$ Mary Beth Mader, “Modern Living and Vital Race: Foucault and the Science of Life," Foucault Studies, 12 (2011), 101-103.

${ }^{34}$ Il faut défendre la société, 227; Society Must Be Defended, 254-5.

35 Translation modified. Macey loses the technical term "condition of acceptability." Il faut défendre la société, 228; Society Must Be Defended, 256.
} 
state murder - or state letting-die or exposure to death, since Foucault's "mise à mort" appears to include indirect killing - continues to occur. ${ }^{36}$ Moreover, the claim that racism is the condition of acceptability of such killing under a certain kind of society is too narrow. Racism has an additional function for the system of power. As I argued above in section I, Foucault's conception of state racism ought to lead him to suspect that racism serves to secure the overall acceptability of the normalizing society itself and not just of state killing. Above all, even if the biopolitically-racialized others are not treated as enemies in any traditional political sense, their position as targets in a state logic of struggle, a polemology, needs to be explicated. Otherwise, Foucault risks making it seem as though there is no strategy within which racism, as state-sanctioned putting-to-death, is operating. Put differently, the imperative of death, that some should be put to death or let die, ends up being derived merely from the possibility of death, or that some can be put to death with impunity. The form of categorization applied to the racially inferiorized is more complicated than SMBD acknowledges; this categorization mixes the political adversary with the biological danger, rather than replacing the former with the latter. Why, then, does this system of power get cemented around the identification and targeting of certain enemies in the first place?

Only by returning to a larger field of struggle can we hope to answer these questions. Racism, in Foucault's terms, is in part a technology of forming and deploying certain politically-relevant continua and discontinua. But this technology is always deployed in a strategic context in which it has the task of identifying, reclassifying, and even disqualifying enemies. A finer-grained analysis would have to consider the various forms of "kill-ability" with which these strategies mark enemies, including death by exposure, but also civil and political death. One might consider, for example, the complex way in which the carceral system in the United States works to strip its targets of access to basic material needs (employment, housing, government assistance), to remove citizenship rights (disenfranchisement, denial of constitutional protections to immigrants), or to impose a permanent suspicion of criminality (every police execution of a black person can be "acceptably" cast as an act of self-defense).

In what follows, I turn to this strategic context by looking at the courses prior to 1976.

\section{A. THE ACCUMULATION OF MEN}

The phrase "accumulation of men" (accumulation des hommes) occurs several times in Foucault's writings from the 1970s. ${ }^{37}$ It looks at times like an ancestor of the concept of biopower and at others like one particular aspect of biopower. Foucault primarily uses the phrase each time he wishes to connect his investigations of power-knowledge to the

\footnotetext{
${ }^{36}$ As Foucault puts elsewhere, the power to make die (faire mourir) becomes a power to "rejeter dans la mort" (Volonté de savoir, 181; History of Sexuality, Vol. 1, 138).

${ }^{37}$ For a somewhat different attempt to link the concept of the "accumulation of men" to Foucault's genealogy of racism, see Orazio Irrera, "Racisme et colonialisme chez Michel Foucault," Rue Descartes (blog), 2015, http://www.ruedescartes.org/recherches-en-cours/racisme-et-colonialisme-chez-michel-foucault/.
} 
dynamics of capitalism. A serious analysis of what Foucault means by this term must thus confront his complex relationship with Marx. At the same time, the term has an immediate intuitive appeal to anyone familiar with the history of racialized slavery, segregation, and apartheid. These two lines of elaboration can only be sketched here, with the hopes of showing how Foucault might contribute to a non-reductionist account of racial capitalism. ${ }^{38}$ The accumulation of human beings, for Foucault, is in a relationship of reciprocal conditioning with the accumulation of capital. He does not make explicit the further relationship between the accumulation of human beings and their racialization, but he does offer some fruitful hints in this direction.

The germ of what Foucault has in mind lies in Marx's polemic against the Malthusianism population theory. Malthus is perhaps best known today for his argument that population growth will outstrip food supply and for the dismal remedies that he thought would impose themselves in such situations. Yet, as Yves Charbit has shown, Malthus's real problem is how to integrate his theory of population into a larger theory of political economy. Malthus came eventually to think that population growth was determined by economic growth, in the shape of the demand for labor. ${ }^{39}$ Marx shares this basic aim of connecting political economy and demography, but he criticizes Malthus's population law for being ahistorical, derived as it is from the premise of a primary biological-sexual instinct. ${ }^{40}$ Malthus focuses unduly on economic growth in the abstract and its correlation to increased demand for labor; he fails to grasp the significance of what Marx calls the composition of capital, or the ratio of constant to variable capital, which reflects changes in the incorporation of science and technology, in the use of machinery, and in the division of labor. ${ }^{41}$ Crucially, Marx moves in Chapter 25 of Capital from an analysis of the population of the working class as such to the significance of the ratio within the working class between the employed segment (the "active army") and the unemployed or surplus population (the "industrial reserve army"). ${ }^{42}$ The existence of a surplus population under capitalism is a structural feature of the mode of production itself and not a result of population growth that has outpaced economic growth. "There must be the possibility of suddenly throwing great masses of men into the decisive areas without doing any damage to the scale of production in other spheres. The surplus population supplies these masses." 43 Marx then traces the further differentiation of the surplus population of the reserve army into four types, the floating, latent, stagnant, and pauperized. ${ }^{44}$

\footnotetext{
${ }^{38}$ In the sense of Cedric J. Robinson, Black Marxism: The Making of the Black Radical Tradition (2000), 2.

${ }^{39}$ Yves Charbit, Economic, Social and Demographic Thought in the XIXth Century: The Population Debate from Malthus to Marx (2009), 1-5, 31.

${ }^{40}$ Charbit, Economic, Social and Demographic Thought, 135-6; Karl Marx, Capital: A Critique of Political Economy [1867](1990), 783-4.

${ }^{41}$ Marx, Capital, 762-4, 766-8n6.

${ }^{42}$ Capital, 781-794.

${ }_{43}$ Capital, 785.

${ }^{44}$ Capital, 794-797.
} 
What must have interested Foucault in this argument is that it refuses any attempt to treat population and capital as independent substances or factors that only enter into relation externally. The processes of human and capital accumulation are not prior to the relation but become what they are only in and through this relation of "adjustment" to one another. Foucault treats these relations as political-technological in nature. What are the technologies of power effecting this adjustment and establishing the lines of differentiation of the population into active and reserve, and the reserve into further subdivisions? The answer, of course, is the new technology of biopower:

This bio-power was without question an indispensable element in the development of capitalism; the latter would not have been possible without the controlled insertion of bodies into the apparatus of production and the adjustment of the phenomena of population to economic processes.... If the development of the great state apparatuses [appareils], as institutions of power, ensured the maintenance of production relations, the rudiments of anatomo- and bio-politics, created in the eighteenth century as techniques of power present at every level of the social body and utilized by very diverse institutions..., operated in the sphere of economic processes, their development, and the forces working to sustain them. They also acted as factors of segregation and social hierarchization, exerting their influence on the respective forces of both these movements, guaranteeing relations of domination and effects of hegemony. The adjustment of the accumulation of men to that of capital, the joining [articulation] of the growth of human groups to the expansion of productive forces and the differential allocation of profit, were made possible in part by the exercise of bio-power in its many forms and modes of application. ${ }^{45}$

In SMBD, the normalizing society sometimes seems to stand on its own, stripped of its relationship with capitalist society. The link between biopower and capital accumulation is somewhat obscured, whereas here it is clearer. Foucault is hardly suggesting, however, that capital accumulation is a fixed end for which biopolitical human accumulation is a mere means; its requirements do not unilaterally determine human accumulation. The two accumulations co-condition one another.

The "adjustment" of population and capital depends on a certain way of inserting bodies into the productive apparatus, an insertion that falls under the heading of what Marx calls the "real subsumption" (subjugation) of labor under capital, or the way in which capital assumes control over the labor process. ${ }^{46}$ This insertion, as Foucault had already shown in Discipline Punish, is double-sided. It aims to make bodies appropriately usable by cultivating fixed aptitudes and capacities that conform to the imperatives of

\footnotetext{
45 Translation corrected. Volonté de savoir, 185-6; History of Sexuality, Vol. 1, 140-141.

${ }^{46}$ For Marx on real and formal subsumption, see Capital, 645 and especially the draft material "Results of the Immediate Process of Production," in Capital, 1018-1039. Although Foucault does not, to my knowledge, ever use the term "real subsumption," Legrand's assessment of Foucault's middle period is largely correct: "On se contenterait de constater avec amusement qu'il [Foucault] a redécouvert le concept de subsomption réelle." Stéphane Legrand, “Le marxisme oublié de Foucault," Actuel Marx 36.2 (2004): 30.
} 
the production process itself; at the same time, this insertion aims to make these bodies governable, to reduce their resistance or unruliness. ${ }^{47}$

Second, since capital accumulation is an unstable and dynamic, but expanding process, the successful insertion of bodies into production depends also on the subsumption of social reproduction under the imperatives of capital. Population growth taken in the abstract does not necessarily meet these demands. The presence of anatomo- and biopolitical techniques of power throughout the social body, and not just in certain localized institutions (such as state apparatuses), ensures what might be called the microadjustments of differentially-classified and subjected groups to these demands. These adjustments remain inseparable from the organs of macro-adjustment, which include the repressive apparatus of the state, but also, later, the state's immigration and eugenics policies and its carceral system. This web of adjustment mechanisms allow for the formation of a docile and divided working population; the same instruments also allow for fresh human material to be thrown in and out of different sectors of production or for warehousing superfluous human material as the need arises.

Race would stand as one category through which this hierarchization and segregation might be organized. It is completely consistent with Foucault's overall argument about the relationship between the state and technologies of power to insist that politicallysignificant forms of hierarchization and segregation are not imposed from top down, but are rooted in a wider network of techniques whose effects are concentrated and partially reorganized by the state apparatuses. But if we consider race to be among these forms of hierarchization and segregation, then we arrive at an important clarification of the thesis in SMBD. Racial difference is not a break introduced by the state (as sovereign) into a monistically-organized population body. The techniques of biopower should be seen as already imposing racial differentiation, prior to the renewed demands of sovereignty.

In a statement from Discipline and Punish (1975), Foucault makes a similar connection between the accumulation of men and the accumulation of capital. He cites links between the incorporation of technological change into the apparatus of production, the re-drawing of the division of labor, and the role of the disciplinary "technology of subjection [assujettissement]." 48 His focus here falls less on the adjustment (coordination, differentiation, hierarchization) of the population as overall mass of humans to capital accumulation than it does on the methods for arranging and disposing human laborpower by way of an assujettissement, in the double sense in which Foucault uses this key term: an inculcation of fixed aptitudes and capacities and a diminution of resistance. ${ }^{49}$ If biopower involves, as Foucault succinctly puts it, "the assujettissement of bodies and the control of populations," the term "accumulation of men" in 1975 still largely designates the former. ${ }^{50}$ In other words, in this earlier usage, the "accumulation of men" is still linked to the somewhat static portrait of capitalist development found in Marx's discus-

\footnotetext{
${ }^{47}$ Foucault, Surveiller et punir, 161, see also 34.

${ }^{48}$ My emphasis. The full quotation can be found at Surveiller et punir, 257; Discipline and Punish, $220-221$.

${ }^{49}$ See above, note 47.

50 Volonté de savoir, 184.
} 
sion of the production of surplus-value (Parts III and IV of Capital), prior to his treatment of the reproduction of capitalism (Part VII).

When this assujettissement is grasped, however, as part of a larger process of human accumulation, a door opens for thinking about assujettissement as a process of racialization. Consider the following remarks from the 1973-4 course Psychiatric Power:

Well, I have the impression that what was in question behind this general setting up of disciplinary apparatuses [dispositifs] was what could be called the accumulation of men. That is to say that, in parallel to the accumulation of capital, and necessary, moreover, for it, it was necessary to go through a certain accumulation of men, or, if you will, a certain distribution of the labor-power [force de travail] that was present in these somatic singularities. ${ }^{51}$

"Accumulation" here means "distribution"; "men" means a certain organization of "somatic singularities." Men, in other words, are not just there, waiting to be gathered up like a bundle of sticks. Their accumulative distribution is first of all the transformation of somatic singularities into intelligible, regular, and calculable entities through the imposition of the form man. In fact, man is both form, or that which allows for the synthesis of the diverse, and norm, or a standard against which the somatic singularities can be made intelligible and open to a political practice that seeks to modify them and train them with respect to this norm. What Foucault says about the accumulation of men can, of course, be tied back to his earlier investigations of the birth of the human sciences (sciences de l'homme). ${ }^{52}$ We do not, unfortunately, have the space to pursue this theme further, but it should be clear that an analysis of the expression "accumulation of men" could provide one important avenue into the problem of relating Foucault's archaeologies of the human sciences in the 1960s to his genealogies of the same in the $1970 \mathrm{~s} .{ }^{53}$ The accumulation of men, then, is best thought of as an accumulation of somatic singularities in accordance with or under the sign of the form-norm man. As such, this process in no way excludes the gathering up of the somatic singularities of women, children, etc.

Somatic singularities are distributed, modified, and organized around a norm of man. But this distribution has the function of extracting from them something like labor-power.

\footnotetext{
${ }^{51}$ The final part of the quotation reads thus: "...une certaine distribution de la force de travail qui était présente dans toutes ces singularités somatiques" (Michel Foucault, Le pouvoir psychiatrique: cours au Collège de France (1973 - 1974), ed. Jacques Lagrange and François Ewald (2003), 73). Translated modified. Burchell has: "a distribution of the labor force with all its somatic singularities" (Michel Foucault, Psychiatric Power: Lectures at the Collège de France, 1973-74, ed. Jacques Lagrange (2008), 71). But force de travail is the standard translation of Marx's Arbeitskraft-labor-power. (Burchell has since avoided this mistake in his translation of The Punitive Society.) Moreover, it is clear that "toutes ces singularités somatiques" is something like a displaced apposite phrase for "hommes" and not a property of some abstract collective entity called the labor force.

${ }^{52}$ This shift, of course, is one of the general themes of Michel Foucault, Les mots et les choses: une archéologie des sciences humaines (1966), 229-233; Michel Foucault, The Order of Things: An Archaeology of the Human Sciences (1994), 217-221. Foucault considers in passing that this shift might have some bearing on the way in which the "problem of races" is posed. Foucault, Les mots et les choses, 319; Foucault, The Order of Things, 307-308.

${ }^{53}$ An exemplary study in this direction is Mader, "Modern Living and Vital Race."
} 
Let us note here that Foucault hardly intends to treat labor-power as a distributive item. "Distribution" has in French a somewhat wider meaning than its cognate in English, and Foucault has in mind the classification, division, and disposition or arrangement of the somatic singularities. ${ }^{54}$ First, this disposition of labor-power seeks to make everyone usable (including women and children), not so that everyone actually can be used, but so that there can be a large reserve army of labor or relative surplus population. What is at issue here is not the homogenization of somatic singularities, but rather their differentiation with respect to the norms of capitalist production and reproduction. Crucially, this new mode of classification is dynamic, but within set bounds: it pins, so to speak, a fixed sphere of trainable capacities to specific types of bodies. It seeks to grasp somatic singularities not in terms of their general properties, but through their peculiar modes of development.

Second, the distribution or disposition of labor-power serves to combine these differentiated and distributed capacities in the most productive way possible while ensuring they remain governable. Disciplinary techniques, Foucault will say in Discipline and Punish, have the function of separating a body's activity from what it can do-literally, from its pouvoir ("power," but also "to be able"). They establish a field of reified capacities susceptible to a certain form of development or training. In sum, the accumulation of men implies both (a) the positing of a measure with respect to which something like labor-power becomes cumulable and (b) the subjection of the somatic singularities to this measure, a subjection that proceeds not simply through external compulsion, but through the inculcation of a certain kind of subjectivity-desires, aptitudes, capacities, dispositions-in the somatic singularities themselves. ${ }^{55}$ Man stands as a finely-graded grid, a hierarchical continuum, with respect to which gender, age, race, and sexual differences can be recoded, situated, and measured. This hierarchy assigns particular groups to particular spheres in the "army" that is the working population (active, reserve, and the further differences in each category). Looking at racial differentiation, in particular, we see that this hierarchy works by picking out not just supposed differences in "economic" aptitudes, but just as much by picking out supposed differences in docility, subordination, compliance, trustworthiness, and perhaps also sense of solidarity with the capitalists. The U.S. discourse of race management, which David Roediger and Elizabeth Esch have recently charted from its development in the Old South into the twentieth century, hardly hid its interest in this latter set of supposedly racial characteristics when it was recruiting labor. ${ }^{56}$ Purely "economic" efficiency is never the exclusive concern under capitalism, or rather concerns about economic efficiency are inseparable from concerns about control. ${ }^{57}$

\footnotetext{
${ }^{54}$ A distribution can be a classificatory ordering of things or people; this meaning is preserved in the term "normal distribution" in English. Similarly, the distribution des rôles in a play refers to the casting process.

${ }^{55}$ Foucault, Le pouvoir psychiatrique, 73-75; Foucault, Psychiatric Power, 71-73.

${ }^{56}$ David R. Roediger and Elizabeth Esch, "'One Symptom of Originality': Race and the Management of Labor in U.S. History," in Class, Race, and Marxism (2017), 115-56.

${ }^{57}$ See the remarks on the relationship between a "system of power" and the mode of production at Société punitive, 235; Punitive Society, 232.
} 
Marx sees capitalist production, unlike previous modes of production, as depending on what he ironically calls "free labor." What he means by this expression is that workers have been emancipated at the juridical level from former relations of bondage and slavery, but also that they have been divested of protective customs and access to the commons through which they might secure their subsistence outside of wage labor. ${ }^{58}$ Here we reach a final sense of the term "accumulation of men." It names those political technologies ensuring that the destruction of traditional social forms of securing a livelihood will lead to a social recomposition, or a gathering-up and fixing of gathered human material onto an apparatus of production. We can see, then, that divestment and emancipation are hardly sufficient conditions of a capitalist labor force. The "freed" must still be motivated to work since running away, whether into vagabondage or some form of marronage, remains a temptation. As Stéphane Legrand writes in his commentary on The Punitive Society: "The capitalist economy conditions and presupposes specific forms of inter-individual dependence that are not archaic residues of previous modes of production, but rather real moments of its development; they are relatively antagonistic to the capitalist exigency of freeing labor." 59 These new forms of bondage, servitude, and slavery may in fact involve new types of juridical subordination, but not necessarily - they may also have their basis in the new technologies of power. The problem of the distribution of labor-power is, then, a problem of the pairing of hierarchical classification of human material according to a circumscribed sphere of educability (docility) with a set of techniques for governing each position of this hierarchy. This pairing is hardly seamless, and it is entirely conceivable that in some situations emancipation would not even be a necessary condition of a capitalist labor force.

Foucault and Marx have both been taxed with neglecting the place of black chattel slavery in their subjects of study. ${ }^{60}$ I noted at the outset of this section that "accumulation of men" calls to mind the slave trade. C.L.R. James had already argued in 1938 that the slaves on the Haitian sugar plantations constituted something like the first modern proletariat. ${ }^{61}$ The current revival of the debate around slavery and capitalism has likewise shed important light on the way in which New World slavery was no mere archaism of the feudal mode of production, but something deeply modern in character. ${ }^{62}$ Using Legrand's interpretation of Foucault, one might respond that juridical emancipation is only a tendency and that there is likewise a tendency toward new forms of subjection. At the limit, systems of formal slavery can certainly be integrated into the capitalist world economy. What is more, Foucault's approach allows for a grasp of the integration

\footnotetext{
${ }^{58}$ Capital, 874-876.

${ }^{59}$ Emphasis in the original. Stéphane Legrand, Les normes chez Foucault (2007), 81, 117.

${ }^{60}$ For Foucault, see the works cited above in note 2. As for Marx, see the discussion, deeply influenced by the work of Oliver Cromwell Cox, in Robinson, Black Marxism, 81ff, 341n47.

${ }^{61}$ C. L. R James, The Black Jacobins: Toussaint L'Ouverture and the San Domingo Revolution (1989), 86, 392.

${ }^{62}$ Edward Baptist, The Half Has Never Been Told: Slavery and the Making of American Capitalism (2014); C. C. Rosenthal, "From Memory to Mastery: Accounting for Control in America, 1750-1880," Enterprise and Society 14.4 (2013), 732-48.
} 
of such systems into a hierarchy of racialized positions in the industrial army, some of which formally count as free.

In sum, Foucault's concept of the accumulation of men attempts to illuminate the imperatives to which the techniques of biopower are responding: capital and human accumulation. I have argued for a non-reductionist interpretation of these imperatives. There are, broadly, two ways in which race could be situated in what Foucault calls the accumulation of men: the racial hierarchization and segregation of the social body and the racial subjectivization (assujettissement) of individual bodies. At the level of microadjustments, race permits multiple, contradictory tasks: pacification and training, segregation and circulation.

\section{B. CLASS STRUGGLE AND THE FIELD OF ILLEGALISM}

Biopower, Foucault says, is what allows for racism to be inscribed in the state. But for this inscription to occur, a process of social hierarchization and segregation must have already taken place. This process answers to the imperative of human accumulation. Now, the accumulation of men does not come off like clockwork. Aside from its own inner contradictions, it encounters resistance from those who are to be accumulated. We must now consider the accumulation of men in light of class struggle. Starting in 1973, Foucault proposes to radicalize Marx's notion of class struggle by analyzing institutions and social practices through the lens of civil war, in which the formation of positions and camps is itself one of the chief stakes of the struggle. Class, then, should be understood in the weak sense here, as one's position vis-à-vis a certain way of producing, and not in the stronger sense of group identity or consciousness. Positions in a stronger sense are formed through struggle and through strategies around struggle, or, to use our term from Part I (above), through logics of enmity. One particularly important example concerns what Foucault calls the question of the "management of illegalisms."

Foucault introduces his concept of illegalism in The Punitive Society lecture course (1973). It continues to play a significant role in Parts II and IV of Discipline and Punish, where it is unfortunately mistranslated as "illegality." 63 Illegalism is to be distinguished from illegality in that the former refers to a sustained strategy of illegal practice, whereas the latter refers to particular actions. ${ }^{64}$ Foucault's basic thesis is that a legal system is only intelligible in light of the larger "field of illegalisms" within which it stands. First, the meaning of any particular positive law cannot be found by comparing it to a natural law as its higher norm or by comparing it directly to the actions it is supposed to regulate; its meaning can only be grasped by situating the particular law in a larger system of laws. Because the ideal of rule of law demands a self-regulating and gapless system (the en-

63 Surveiller et punir, 98-106, 299-342; Discipline and Punish, 82-89, 257-292. "Illégalisme" is also mistranslated as "illegality" in Michel Foucault, "Alternatives to the Prison: Dissemination or Decline of Social Control?" Theory, Culture \& Society 26.6 (2009), 12-24 (the original is Michel Foucault, "Alternatives à la prison: Diffusion ou décroissance du contrôle social," Criminologie 26.1 [1976](1993), 13-34.

${ }^{64}$ On the difference between illégalisme and illégalité, see Marcio Alves da Fonseca, Michel Foucault et le Droit (2014), 93-96; Pierre Lascoumes, “L'illégalisme, outil d'analyse," Sociétés et Représentations 3 (1996), 78-84. 
actment and application of laws is itself regulated by law), an actually-existing system of laws may appear to be something free-standing and detached from other social relations. Radical legal scholars have long observed that this detachment is an illusion, and that laws are made and enforced in ways that serve the interests of dominant social groups. The law is not really neutral, and, in a capitalist and racist society, it has a class and race character. It might be thought that this non-neutrality manifests itself in the legal system's attempt to suppress working class crime while neglecting bourgeois crime.

Foucault's point is somewhat different. He starts from the premise of generalized illegalism. All social actors break the law, and the quotidian existence of the principal social groups typically depends on various strategies of law-breaking. Illegalism is "logically" prior to legality: "A law functions and is applied [s'applique] only within a field of illegalism that is actually practiced and that, in a way, supports it." 65 The effective meaning of a system of laws only becomes clear once its false detachment is stripped away and the system is understood as a way of handling a pre-existing field of practices and actions. What laws actually do is much more complex than prohibit and permit, and what a legal system like ours aims at is not, strictly speaking, the suppression of crime. Instead, it establishes salient differences between types of prohibited actions. "A penal system must be conceived as a mechanism for managing illegalisms differentially, and not for suppressing them all." 66 To manage differentially is first of all to impose a system of differences itself. These differences are partially of a legal character, as in the distinction between types of crime: between misdemeanors and felonies, of course, but consider also the legal protocols governing drug crime or workplace infractions in the U.S., or the different types of penalties attaching to white- and blue-collar crime. The differences in question are also of a larger social character. A process of "social euphemization," as Lascoumes puts it, occurs around certain kinds of acts (e.g., wage theft), whereas other kinds of acts are linked to socially-dangerous elements and become special objects of study and policy ${ }^{67}$ The differential management of illegalisms is the name Foucault gives to the techniques whereby a new pattern of dividing up, classifying, monitoring, and handling the field of illegalisms is established. Foucault would agree, however, that this differential management has a class and race character.

What Foucault came to see in the interval between Penal Institutions and Theories (the 1972 course) and The Punitive Society (1973) was that the growth of a state-controlled apparatus of justice should be grasped as way of reorganizing illegalisms. In the debate with the Maoists and in other interviews, as well as in the 1972 course, he had treated the birth of modern, state-controlled forms of justice (la justice armée, as he puts it ane point) as a response to peasant insurrection (la plèbe séditieuse). The function of the justice and penal systems is to drive a wedge between the proletarianized and the unproletari-

\footnotetext{
65 Société punitive, 148-9; Punitive Society, 145.

${ }_{66}$ Translation modified. Surveiller et punir, 106; Discipline and Punish, 89.

${ }^{67}$ Lascoumes, “L'illégalisme, outil d'analyse,” 82-84.
} 
anized plebs by repressing the illegal activity of the latter. ${ }^{68}$ But in the lecture of 21 February 1973, he abandons this argument, for he seems to have thought it begged certain questions about class formation. In particular, the "seditious plebs" thesis failed to account for the way in which the (French) bourgeoisie achieved political and social power and self-formation as a class through an initial collaboration with the plebs and newlyformed proletariat. ${ }^{69}$ The seventeenth and early eighteenth centuries were characterized by a continuum of popular illegalisms, in which there is no clear class break between types of crime. But at the end of the eighteenth century, the bourgeoisie sought, after it had achieved social coherence and some political power, to break up this continuum into qualitatively distinct categories and to establish a special field of delinquency separate from the general field of infraction. ${ }^{70}$ It is when Foucault faces the question of this breakup of popular illegalism that he begins to move away from the study of state apparatuses to an account of power in terms of a network of technologies circulating throughout the entire social body.

In the historical portion of Foucault's treatment of popular illegalism, he argues that illegalism was general in late feudal society. It was both common to all social groups and also a point of contact and shared practice between the three estates. The nascent bourgeoisie and the lower classes, for example, both used certain practices of fraud and smuggling to get around feudal regulations on production and trade..$^{71}$ Illegalism mixed economic and political resistance. It was "popular" and "continuous" precisely in the sense that it was not yet coded as the sphere of one social group or class-it was of the people, in the amorphous political sense of that term.

The introduction of the carceral system at the end of the eighteenth century serves to break up this popular continuum, or to break up the people itself and introduce a new mode of political classification. ${ }^{72}$ In both The Punitive Society and in Discipline and Punish, Foucault offers slightly distinct accounts of why this change occurred. In both places, however, the growth of new kinds of property, namely, the productive apparatus itself, made it imperative to control and police theft from workers, or what Foucault calls the "illegalism of goods." At the same time, the bourgeoisie's monopoly over the means of production gave it an effective monopoly over the "illegalism of rights," such as smuggling, fraud, or counterfeiting, which now took on a more highly organized and professionalized character. A class wedge thus emerged between the illegalism of goods and the illegalism of rights. At the same time, the bourgeoisie began to target a whole level of "infra-legal illegalism" on the part of the working class. Foucault names this level the

\footnotetext{
${ }^{68}$ DE I no. 108, 1219; see also DE I no. 107, 1202 and the editors' note at Théories et institutions pénales, 3435 n13.

69 Société punitive, 144; Punitive Society, 140.

70 Société punitive, 153; Punitive Society, 150. Burchell translates "illégalisme populaire" as "lower-class illegalism," which is technically correct from the perspective of contemporary French usage; however, it misses the way in which the people stands as amorphous political category comprising the entirety of the Third Estate under the Ancien Régime.

71 Surveiller et punir, 103; Discipline and Punish, 86-87.

72 See above, note 70 .
} 
“illegalism of dissipation." Workers must be made productive; must offer their laborpower regularly on the labor market without running off into combinations, unions, or non-wage forms of subsistence; and must be prevented from dissipating or damaging their labor-power by drinking, carousing, or vagabondage. ${ }^{73}$

What is crucial, then, is that the new management of illegalisms does more than just introduce a new principle of differentiation (infractions of theft versus infractions of fraud) into the old continuum of illegalisms. It also, in targeting this further "illegalism of dissipation," qualifies an entire class of society as essentially criminal. It breaks the category people itself up into bourgeoisie and proletariat along the lines of the lawabiding and the potentially criminal. This new management then breaks proletarianized mass itself up into a possibly "correctable" element whose labor-power can be properly disposed and an incorrigible element, while establishing a finally graded continuum of degrees between them. Although Foucault only offers us a sketch, it is easy enough to see how the new way of managing illegalisms that emerges in the nineteenth century might connect up with the biopolitical techniques of social hierarchization and segregation.

Foucault was fond of quoting the lawyer Guy-Jean-Baptiste Target, who gives crime a class and racial character: "For such a nation, penalties must almost always be gauged by reference to the nature of this bastard race [race abâtardie], which is the source of crimes, and the regeneration of which can barely be glimpsed, after many years of the wisest government." ${ }^{74}$ Unlike some of his liberal contemporaries, Target frankly embraces a non-neutral, racialized legal and penal system. Although Foucault never explores the racial aspect of this statement further, it seems clear that he was interested in what might be called Europe's internal racialism, or the discourse of intra-European racial difference, as well as the process of Europe's internal colonization that in many ways preceded and then developed in tandem with external colonization. ${ }^{75}$

In SMBD, biopower constitutes the population as a biologico-political continuum; the state, in taking up racial technology, then introduces qualitative breaks in this continuum. But this sketch is greatly enriched when the relationship between the population and other relevant political continua and discontinua is brought to light. We have only been able to hint here at how Foucault's genealogy of technologies for managing illegalism might contribute to such an enriched account. The emergence of the population as political category alongside the people should also be located in the break-up of the popular continuum of illegalisms. Once again, a new process of segregation and hierarchization is at work in the social body, and, once again, this process at very least predelineates a place for racialization and racial categories. Once more, Foucault alludes to race without elaboration. The logic of racial enmity taken up by the state in the form of what

\footnotetext{
73 Société punitive, 191-3; Punitive Society, 187-188.

${ }^{74}$ Target, "Observations sur le Projet de Code criminel" (1810) quoted in Société punitive, 167; Punitive Society, 164. Target is also cited in Surveiller et punir, 321; Discipline and Punish, 275-6.

${ }_{75}$ On the theme of intra-European colonization in Foucault, see Irrera, "Racisme et colonialisme chez Michel Foucault."
} 
Foucault calls state racism has one of its most important conditions here, in the strategy of social enemyship that guides the new management of illegalisms.

\section{CONCLUSION}

I have argued that the famous lecture of 17 March 1976 should not be read as a freestanding account of state racism, but as an extremely compressed précis of a number of threads Foucault had pursued during his initial period at the Collège de France. Standing in the background of SMBD is his earlier analysis of the "accumulation of men" and of the implicitly racialized "differential management of illegalisms." I could also have mentioned the sketch of a genealogy of heredity that runs from Foucault's application to the Collège de France to the discussion of the new "dynastic bodies" and sexuality at the end of The Punitive Society and of the ancestral or hereditary "metabody" as explanatory ground of abnormality in Psychiatric Power and Abnormal; that sketch culminates in his brief remarks on the collective corporeal "self-affirmation" of the bourgeoisie in WK. ${ }^{76} \mathrm{I}$ have likewise had to pass over the more familiar, but equally important, contribution Foucault makes in WK to conceptualizing the reciprocal constitution of race and sexuality. What I have tried to show in this paper is that the genealogy of state racism from 1976 is informed by the entire series of genealogical investigations leading up to it. Restoring this series makes the account in SMBD less vague and gives it more internal articulation and differentiation. It is especially important to understand how biopolitical racism mixes together economic, juridical, punitive, scientific, and political functions. Above all, Foucault's insight into the connection between human and capital accumulation almost leads him to grasp the non-contingent relationship of co-conditioning between racism and capitalism. There are resources in Foucault that contribute to the genealogy of what Cedric Robinson has called racial capitalism. ${ }^{77}$

State racism is the privileged object of investigation in SMBD. But state racism is a complex object. It works through and depends upon techniques of racialism and racialization, and its aim includes both the elimination of threats and enemies to the social order and the reinforcement of the legitimacy and acceptability of the existing system of power. The instruments of state racism are only able to function this way because they are rooted in a wider field of power relations. Perhaps most controversially, I have argued that Foucault accepts that this wider field is importantly structured-although hardly mechanistically caused-by the dynamics of capitalist development. Racism, however, is not simply an ideology used to divide workers from one another. It is (i) a fundamental condition of the new rationalities of subjectivization and unfreedom implicit in capitalist domination and exploitation and is, indeed, the very backdrop against

\footnotetext{
${ }^{76}$ DE I no. 71, 870-874; Punitive Society, 206ff; Michel Foucault, Abnormal: Lectures at the Collège de France, 1974-1975, ed. Valerio Marchetti, Antonella Salomoni, and Arnold Ira Davidson(2003), 315-317; History of Sexuality, Vol. 1, 123ff. See also Mary Beth Mader, "Foucault's 'Metabody,'” Journal of Bioethical Inquiry 7.2 (2010), 187-203.

77 See above, note 38 .
} 
which the emergence of juridically "free" labor should be thought; it is (ii) a fundamental concept (race) and technique (racialization, race management) in the "accumulation of men" on which capitalism depends; and (iii) a way of recoding illegalisms and thereby of recoding class struggle by euphemizing certain actions and imbuing other actors with a permanent aura of criminality and dangerousness. The capitalist imperative of "accumulating men" and the class struggle that attends this imperative condition the emergence of new technologies for training and directing aptitudes, capacities, and reproduction. They also condition new strategies for negotiating this struggle-they condition a new logic of enmity.

It is this logic that the centralized state apparatus takes up and recodes. Sometimes, the state deploys this logic in the service of a program of mass murder. But the state also takes over the more mundane and daily task of defining and managing racial division in ways that maintain the present system of power. Foucault claims in 1976 that racism is the condition of acceptability of killing under a biopolitical system of power. He should have also insisted-and indications in his earlier courses point in this direction-that racism is an integral factor in making acceptable the larger system of power characteristic of the normalizing capitalist society. ${ }^{78}$

\section{References}

Alves da Fonseca, Marcio, Michel Foucault et le Droit. Paris: Editions L'Harmattan, 2014.

Balibar, Etienne, "Appareil," in Dictionnaire critique du marxisme, ed. Gérard Bensussan and Georges Labica, 47-54. Paris: PUF, 1999.

Baptist, Edward, The Half Has Never Been Told: Slavery and the Making of American Capitalism. New York, NY: Basic Books, 2014.

Bernasconi, Robert, "The Policing of Race Mixing: The Place of Biopower within the History of Racisms," Journal of Bioethical Inquiry 7.2 (2010), 205-16. https://doi.org/10.1007/s11673-010-9224-8

Brossat, Alain, "Le peuple, la plèbe et la pègre," Lignes 21.1 (1994), 35-44. https://doi.org/10.3917/lignes0.021.0035

Castro-Gómez, Santiago, "Michel foucault y la colonialidad del poder," Tabula Rasa 6 (2007), 153-72. https://doi.org/10.25058/20112742.290

Charbit, Yves, Economic, Social and Demographic Thought in the XIXth Century: The Population Debate from Malthus to Marx. New York, NY: Springer, 2009. https://doi.org/10.1007/978-1-4020-9960-1

Davidson, Arnold Ira, "Ethics as Ascetics: Foucault, the History of Ethics, and Ancient Thought," in The Cambridge Companion to Foucault, ed. Gary Gutting, 2nd ed., 123-48. Cambridge: Cambridge University Press, 2005.

Foucault, Michel, Abnormal: Lectures at the Collège de France, 1974-1975, ed. Valerio Marchetti, Antonella Salomoni, and Arnold Ira Davidson. New York, NY: Picador, 2003.

${ }^{78}$ I would like to thank Orazio Irrera for helpful remarks on an earlier version of this paper. 
Foucault, Michel, "Alternatives à la prison: Diffusion ou décroissance du contrôle social?" [1976], Criminologie 26.1 (1993): 13-34. https://doi.org/10.7202/017328ar

Foucault, Michel, "Alternatives to the Prison: Dissemination or Decline of Social Control?" [1976], Theory, Culture \& Society $26.6 \quad$ (2009): 12-24. https://doi.org/10.1177/0263276409353775.

Foucault, Michel, Discipline and Punish: The Birth of the Prison [1975]. New York: Vintage Books, 1995.

Foucault, Michel, Dits et écrits. 1954-1988, ed. Daniel Defert, François Ewald, and Jacques Lagrange. 2 vols. Paris: "Quarto" Gallimard, 2001.

Foucault, Michel, "Il faut défendre la société": cours au Collège de France, 1975-1976, ed. Mauro Bertani and Allesandro Fontana. Paris: Gallimard/Seuil, 1997.

Foucault, Michel, La société punitive: cours au Collège de France, 1972-1973, ed. François Ewald. Paris: Gallimard/Seuil, 2013.

Foucault, Michel, La volonté de savoir. Paris: Gallimard, 1976.

Foucault, Michel, Le pouvoir psychiatrique: cours au Collège de France, 1973-1974, ed. Jacques Lagrange and François Ewald. Paris: Gallimard/Seuil, 2003.

Foucault, Michel, Les mots et les choses: une archéologie des sciences humaines. Paris: Gallimard, 1966.

Foucault, Michel, Psychiatric Power: Lectures at the Collège de France, 1973-74, ed. Jacques Lagrange. New York, NY: Picador, 2008.

Foucault, Michel, Sécurité, territoire, population: cours au Collège de France, 1977-1978, ed. Michel Senellart and François Ewald. Paris: Gallimard/Seuil, 2004.

Foucault, Michel, Security, territory, population: lectures at the Collège de France, 1977-1978, ed. Michel Senellart and François Ewald. New York: Picador/Palgrave Macmillan, 2009.

Foucault, Michel, "Society Must Be Defended": Lectures at the Collège de France, 1975-76, ed. Mauro Bertani and Alessandro Fontana. New York: Picador, 2003.

Foucault, Michel, Surveiller et punir: naissance de la prison [1975]. Paris: Gallimard/Tel, 1993.

Foucault, Michel, The History of Sexuality, Vol. 1: An Introduction [1976]. New York: Vintage Books, 1990.

Foucault, Michel, The Order of Things: An Archaeology of the Human Sciences [1966]. New York NY: Vintage Books, 1994.

Foucault, Michel, Théories et institutions pénales: cours au Collège de France, 1971-1972, ed. François Ewald, Alessandro Fontana, and Bernard E. Harcourt. Paris: Gallimard/Seuil, 2015.

Foucault, Michel, The Punitive Society: Lectures at the Collège de France, 1972-1973, ed. Bernard E. Harcourt and Alessandro Fontana. New York: Palgrave Macmillan, 2015.

Foucault, Michel, and Pierre Vidal-Naquet, "Enquête sur les prisons: brisons les barreaux du silence," in Dits et écrits. 1954-1975, ed. Daniel Defert, François Ewald, and Jacques Lagrange, 1:1044-50. Paris: “Quarto" Gallimard, 2001.

Goldberg, David Theo, Racist Culture: Philosophy and the Politics of Meaning. Oxford: Blackwell, 1993.

Goldberg, David Theo, The Racial State. Malden, MA: Blackwell, 2002. 
Irrera, Orazio, "Racisme et colonialisme chez Michel Foucault," Rue Descartes (blog), 2015. http://www.ruedescartes.org/recherches-en-cours/racisme-et-colonialisme-chezmichel-foucault/

James, C. L. R., The Black Jacobins: Toussaint L'Ouverture and the San Domingo Revolution [1938]. New York: Vintage Books, 1989.

Jessop, Bob, "From Micro-Powers to Governmentality: Foucault's Work on Statehood, State Formation, Statecraft and State Power," Political Geography 26.1 (2007), 34-40. https://doi.org/10.1016/j.polgeo.2006.08.002

Lascoumes, Pierre, “L'illégalisme, outil d'analyse," Sociétés et représentations 3 (1996), 7884. https://doi.org/10.3917/sr.003.0078

Legrand, Stéphane, "Le marxisme oublié de Foucault," Actuel Marx 36.2 (2004), 27-43. https://doi.org/10.3917/amx.036.0027

Legrand, Stéphane, Les normes chez Foucault. Paris: PUF, 2007.

Mader, Mary Beth, "Foucault's 'Metabody,'” Journal of Bioethical Inquiry 7.2 (2010), 187203. https://doi.org/10.1007/s11673-010-9237-3

Mader, Mary Beth, "Modern Living and Vital Race: Foucault and the Science of Life," Foucault Studies 12 (2011), 97-112. https://doi.org/10.22439/fs.v0i12.3336

Marx, Karl, Capital: A Critique of Political Economy, ed. Ernest Mandel. London and New York, NY: Penguin Classics and New Left Review, 1990.

Marx, Karl, "Results of the Immediate Process of Production," in Capital: A Critique of Political Economy, ed. by Ernest Mandel, 948-1084. London and New York, NY: Penguin Classics and New Left Review, 1990.

Robinson, Cedric J., Black Marxism: The Making of the Black Radical Tradition. Chapel Hill: University of North Carolina Press, 2000.

Roediger, David R., and Elizabeth Esch, "'One Symptom of Originality': Race and the Management of Labor in U.S. History," in David Roediger, Class, Race, and Marxism, 115-56. London and New York, NY: Verso, 2017.

Rosenthal, C. C., "From Memory to Mastery: Accounting for Control in America, 17501880," Enterprise and Society 14.4 (2013), 732-48. https://doi.org/10.1093/es/kht086

Rousseau, Jean-Jacques, Basic Political Writings, ed. Donald A. Cress, 2nd ed. Indianapolis, IN: Hackett, 2011.

Said, Edward W., Beginnings: Intention and Method. New York: Basic Books, 1975.

Said, Edward W., Reflections on Exile and Other Essays. Cambridge, MA: Harvard University Press, 2000.

Senellart, Michel, "Le cachalot et l'écrevisse. Réflexions sur la rédaction des cours au Collège de France," Cahiers de l'Herne 95 (2011), 147-55.

Stoler, Ann Laura, Race and the Education of Desire: Foucault's History of Sexuality and the Colonial Order of Things. Durham, NC: Duke University Press, 1995.

Young, Robert, "Foucault on Race and Colonialism," New Formation 25 (1995), 57-65. 
Author info

Alex J. Feldman, PhD

Department of Philosophy

The Pennsylvania State University

Pennsylvania, USA

ajf251@psu.edu 